\title{
The Rapidly Deepening India-China Economic Relationship
}

\author{
John Whalley \\ Tanmaya Shekhar
}

CESIFO WORKING PAPER NO. 3183

CATEgORY 8: TRAde POLICY

SEPTEMBER 2010
An electronic version of the paper may be downloaded
- from the SSRN website:
- from the RePEc website:
- from the CESifo website:
www.SSRN.com
www.RePEc.org
www.CESifo-group.org/wp




\title{
The Rapidly Deepening India-China Economic Relationship
}

\begin{abstract}
In this paper we focus on the rapidly deepening bilateral India-China economic relationship. Each is deeply integrating into the global economy through trade and FDI inflows, China is seen as primarily manufacturing-lead growth with India as service-lead growth (see Rodrick \& Subramanian (2006)). An alternative view is that India is effectively a lagged version of China, and the two have to be considered a joint global presence. India and China are thus viewed in the literature in different comparative mode. That their bilateral closeness is deepening is evident in a number of areas. On the trade front, India-China bilateral trade has increased by a factor of 33 between 1995 and 2007, and this growth has occurred at an accelerating rate. This compares with a 7 fold increase in the China's overall trade this period. With bilateral FDI the increase is even more dramatic, around 90 fold over the same period, but admittedly from a small base. And while strategic issues remain between India and China since they are complicated by the relationships of each other with Pakistan, on bilateral economic policy coordination there has also been considerable joint movement towards joint positions. There has been a feasibility study for a possible India-China FTA. They have also jointly agreed a bilateral pact on climate policy underpinning their joint negotiating stance in Copenhagen in 2009 on a post Kyoto global climate regime; and in international forums such as the WTO (and specifically in the Doha Round) both countries have supported each others' positions, and especially so in key meetings such as in July 2008 in Geneva.
\end{abstract}

JEL-Code: F10.

Keywords: India, China, deepening, trade, FDI, policy coordination.

John Whalley

University of Western Ontario

jwhalley@uwo.ca
Tanmaya Shekhar

Indian Institute of Technology, Kanpur

tshekhar@iitk.ac.in

July 2010

We are grateful to the Ontario Research Fund (ORF) for financial support and to Wang Jing and Mohan Agarwal for all their help, comments and discussion. 


\section{Introduction}

China and India together comprise around $40 \%$ of the world population and are widely seen as a large pool of low wage labour restrained in international mobility by OECD immigration restrictions. The effective entry of India and China into the global economy from the early 1990’s generated opportunities for extensive global arbitrage in goods trade embodying low wage labour, FDI inflows to access low wage labour, outsourcing from the OECD, and transfer from the OECD of labour intensive service functions in call centers and other activities. The result has been a pronounced growth surge in these economies; in the last decade (or more) in the Indian case and over the last two decades in the Chinese case. Despite the Financial Crisis, GDP growth in the last quarter of 2009 was $8.8 \%$ in India and in the first quarter of 2010 was 11.9\% in China. A widely held view is that this elevated growth performance could persist for several more decades, and if so, India and China will jointly provide growing and eventually major influence over the global economy.

In this paper we focus on one element of these developments; the rapidly deepening bilateral India-China economic relationship. India and China are viewed in the literature in different comparative modes. Each is deeply integrating into the global economy through trade and FDI inflows. China is seen by some as primarily manufacturing-lead growth with India as service-lead growth (see Rodrick \& Subramanian (2006)). An alternative view is that India is effectively a lagged version of China, and the two have to be considered a joint global presence.

That their bilateral closeness is deepening is evident in a number of areas. On the trade front, India-China bilateral trade has increased by a factor of 33 between 1995 and 2007, and this growth has occurred at an accelerating rate. This compares with a 7 fold increase in China's overall trade this period. With bilateral FDI the increase is even more dramatic, around 90 fold 
over the same period, but admittedly from a small base. And while strategic issues remain between India and China such as the relationship of each with Pakistan, on bilateral economic policy coordination there has also been considerable joint movement towards joint positions.

There has been a feasibility study for a possible India-China FTA. They have also jointly agreed a bilateral pact on climate policy underpinning their joint negotiating stance in Copenhagen in 2009 on a post Kyoto global climate regime; and in international forums such as the WTO (and specifically in the Doha Round) both countries have supported each others’ positions, and especially so in key meetings such as in July 2008 in Geneva.

In what follows, we document not only the clear deepening of the China-India economic relationship, but also emphasize the growing acceleration of this trend in the most recent years. We present data on bilateral trade and FDI flows and highlight its product and sector composition, as well as its regional intensity for each of the two economies. We also present recent data showing how these trends have been affected by the financial crisis. We then use the data as a basis to make forward projections, which points surprisingly quickly to an emerging globally significant profile for the India-China relationship. We finally document the growing policy coordination occurring bilaterally, and discuss its future potential evolution.

\section{Economic Performance in China and India}

Both India and China have achieved high growth rates by historical standards in recent years. India has been growing in the last five years before the crisis at rates which match those of Japan in the 1960's and Korea in the late 1970's. This growth has progressively accelerated since major reforms were initiated in 1989-1991. China has been growing at even higher and unprecedented rates which pre-crisis touched 13\% per year. 
The pace of the change which these growth rates imply is breathtaking. China's $11^{\text {th }}$ Five Year Plan in 2005 set a minimum target for China’s long-term growth of 7.5\% per year, a target which has already been easily exceeded. Growth at $7.5 \%$ a year over 50 years yields a 30-fold increase in real GDP per capita. But not only is the issue the global impact from separate high growth by India and China, but also the input of their even more rapid growth and acceleration in growth of joint interdependence and hence their emergence as a progressively cohesive economic bloc in the decades ahead.

The main features of their growth performance are set out in Tables 2.1 and 2.2. Table 2.1 reports GDP/Capita in constant 2000 US dollars. Between 1998 and 2009 China experienced an 8 fold increase in GDP/capita. In the late 70's and early 80's India had GDP/Capita above that of China, but now lags by almost 3:1. In purchasing power parity terms, World Bank data suggest that as late as 1992 India had GDP/capita above China, but in 2008 the gap was also nearly 3:1 in favour of China. The gap between India and China has thus widened substantially in the last 15 years due to more rapid growth in China. Table 2.2 reports annual growth rates since 1994.

Behind these two aggregate growth profiles there are both similarities and differences. The similarity is the common integration in to the global economy in each case. As Table 2.3 indicates, the share of trade (combined exports and imports) relative to GDP has increased sharply for each country. In the Indian case this is from $16 \%$ of GDP to $46 \%$ of GDP in 2007. In China's case, it is from 35\% in 1990 to $70 \%$ in 2007. Equally, there are large increases in FDI inflows. The increase in the Chinese case from 1990 to 2007 is from around \$ 2 billion/year to $\$ 70$ billion. The increase in India occurs considerably later, but still increases from $\$ 2$ billion/year in 2003 to $\$ 20$ billion in 2008. Growth in bilateral trade and FDI flows between 
Table 2.1: GDP per Capita for India and China, 1994-2008 (2000 US \$)

\begin{tabular}{|c|r|r|}
\hline Year & India & China \\
\hline 1994 & 351.87 & 599.80 \\
\hline 1995 & 371.81 & 658.00 \\
\hline 1996 & 392.92 & 716.25 \\
\hline 1997 & 401.79 & 774.89 \\
\hline 1998 & 419.40 & 827.35 \\
\hline 1999 & 442.79 & 882.56 \\
\hline 2000 & 452.97 & 949.18 \\
\hline 2001 & 468.96 & $1,020.52$ \\
\hline 2002 & 479.12 & $1,105.96$ \\
\hline 2003 & 511.54 & $1,209.00$ \\
\hline 2004 & 546.03 & $1,323.23$ \\
\hline 2005 & 588.99 & $1,452.28$ \\
\hline 2006 & 637.08 & $1,611.71$ \\
\hline 2007 & 685.55 & $1,811.75$ \\
\hline 2008 & 717.51 & $1,964.71$ \\
\hline
\end{tabular}

Source: World dataBank- http://databank.worldbank.org/ddp/home.do 
Table 2.2: GDP Growth Rates for India and China, 1994-2008 (Annual \%)

\begin{tabular}{|c|r|r|}
\hline Year & India & China \\
\hline 1994 & 6.65 & 13.10 \\
\hline 1995 & 7.57 & 10.90 \\
\hline 1996 & 7.56 & 10.00 \\
\hline 1997 & 4.05 & 9.30 \\
\hline 1998 & 6.19 & 7.80 \\
\hline 1999 & 7.39 & 7.60 \\
\hline 2000 & 4.03 & 8.40 \\
\hline 2001 & 5.22 & 8.30 \\
\hline 2002 & 3.77 & 9.10 \\
\hline 2003 & 8.37 & 10.00 \\
\hline 2004 & 8.28 & 10.10 \\
\hline 2005 & 9.35 & 10.40 \\
\hline 2006 & 9.67 & 11.60 \\
\hline 2007 & 9.06 & 13.00 \\
\hline 2008 & 6.07 & 9.00 \\
\hline
\end{tabular}

Source: World dataBank- http://databank.worldbank.org/ddp/home.do 
Table 2.3: Trade (Imports plus Exports) as \% of GDP, for India and China, 1994-2008

\begin{tabular}{|l|r|r|}
\hline Year & India & China \\
\hline 1994 & 20.31 & 47.31 \\
\hline 1995 & 23.13 & 43.94 \\
\hline 1996 & 22.19 & 38.06 \\
\hline 1997 & 22.89 & 39.01 \\
\hline 1998 & 23.98 & 36.39 \\
\hline 1999 & 25.28 & 37.97 \\
\hline 2000 & 27.38 & 44.24 \\
\hline 2001 & 26.41 & 43.08 \\
\hline 2002 & 29.97 & 47.70 \\
\hline 2003 & 30.90 & 56.91 \\
\hline 2004 & 37.94 & 65.35 \\
\hline 2005 & 42.53 & 69.28 \\
\hline 2006 & 47.44 & 72.03 \\
\hline 2007 & 45.88 & 70.28 \\
\hline 2008 & 50.70 & 65.05 \\
\hline
\end{tabular}

Source: World dataBank- http://databank.worldbank.org/ddp/home.do 
India and China must therefore be seen relative to the growth occurring in their total trade and FDI flows.

But there are also differences. In the Indian case, one is a sharper rise in service related exports and the role of services more generally in the growth process and especially so for information technology related services. This growth has also been accompanied by substantial outsourcing of labour intensive services to India, and is in part reflective of India's language situation, especially in such areas as call centres. Bilateral service flow data between India and China are not available, but service exports as a percentage of total exports of goods and services grow from $20.2 \%$ in 1990 for India to $35.4 \%$ in 2008 while in China they fall from $10.2 \%$ in 1990 to $9.3 \%$ in $2008 .^{2}$ Another difference has been the later growth of exports in the Indian case. Also a sharp increase in the inequality has occurred in the Chinese case with regional concentration of growth in coastal zones, this has not occurred in the Indian case.

Table 2.4 reports data on the industry composition of growth. India’s growth post trade liberalization in 1991 has been accompanied by a small percent increase in services while manufacturing has more heavily led China’s growth. In both cases the share of agriculture declines, and especially so in China.

Between 1950 and 1990, agriculture’s share in India in GDP declined by 25 \% while the share of industry and services both increased. Industry’s share is roughly constant after 1990 and the subsequent decline in agriculture is accompanied by a similar increase for the service sector. But, despite a decline in the share of agriculture in GDP, there has not been a decline in the share of agriculture in employment. Equally, the share of services in GDP has risen but with no

\footnotetext{
${ }^{2}$ See World Data Bank: http://databank.worldbank.org/ddp/home.do
} 
Table 2.4: Comparison of Sector Wide Composition of GDP in India and China, 1990-2008

\begin{tabular}{|l|l|l|l|l|l|l|}
\hline Year & \multicolumn{2}{|l}{ Agriculture (\% of } & \multicolumn{3}{l|}{ Industry(\% of GDP) } & \multicolumn{2}{l|}{ Services(\% of GDP) } \\
\hline & India & China & India & China & India & China \\
\hline 1990 & 29 & 27 & 27 & 41 & 44 & 32 \\
\hline 1991 & 30 & 24 & 25 & 42 & 45 & 34 \\
\hline 1992 & 29 & 22 & 26 & 43 & 45 & 35 \\
\hline 1993 & 29 & 20 & 26 & 46 & 45 & 34 \\
\hline 1994 & 28 & 20 & 27 & 46 & 45 & 34 \\
\hline 1995 & 26 & 20 & 28 & 47 & 46 & 33 \\
\hline 1996 & 27 & 20 & 27 & 48 & 46 & 32 \\
\hline 1997 & 26 & 18 & 27 & 48 & 47 & 34 \\
\hline 1998 & 26 & 18 & 26 & 46 & 48 & 36 \\
\hline 1999 & 25 & 16 & 25 & 46 & 50 & 38 \\
\hline 2000 & 24 & 15 & 26 & 46 & 50 & 39 \\
\hline 2001 & 23 & 14 & 26 & 46 & 51 & 40 \\
\hline 2002 & 21 & 14 & 26 & 45 & 53 & 41 \\
\hline 2003 & 21 & 13 & 26 & 46 & 53 & 41 \\
\hline 2004 & 19 & 13 & 28 & 47 & 53 & 40 \\
\hline 2005 & 19 & 12 & 29 & 48 & 52 & 40 \\
\hline 2006 & 18 & 11 & 29 & 49 & 53 & 40 \\
\hline 2007 & 18 & 11 & 30 & 49 & 52 & 40 \\
\hline 2008 & 17 & 11 & 29 & 49 & 54 & 40 \\
\hline 5040 & W0 & & & 53 & \\
\hline
\end{tabular}

Source: World dataBank - http://databank.worldbank.org/ddp/home.do 
increase in the share in employment. In China, in contrast, the share of employment in the service sector has increased steadily since 1978 and China’s service sector now employs relatively more labour than in India. In India the decline in service employment has been accompanied by an increase in labour productivity. This has been due to the growth of services in sub-sectors which employ more skilled labour.

India has also experienced fast growth in outsourcing, achieving an average annual growth of 37\% between 2004-2008. Despite the financial crisis of 2008, services outsourcing in China grew at 54\% year on year to $\$ 1.6$ billion. However, China still significantly lags India. The same year, India accounted for nearly $37 \%$ of global outsourcing, while China was less than $10 \%$. A future problem for Indian outsourcing activity could be wage levels. The ratio of wages in the related services sector in India and the USA was 1:6 but it is nearly 1:3 in early 2009 while the ratio of similar service sector wages in China and the USA is about 1:7. This difference partly reflects the more detailed composition of the two service sectors but cost factors might prompt a shift of outsourcing from India to China in the future. However, outsourcing clients also focus on service capabilities, including intellectual property protection and language skills. China has weaker intellectual property protection and has fewer skilled IT workers in areas such as business process, management and interpersonal communication ${ }^{34}$.

Table 2.5 highlights some of the differences China and India’s growth experience over the last 20 years. The patterns have mostly been similar, the difference arising primarily in the rates at which different sectors have been progressing, causing many to prompt that India is

\footnotetext{
3 - http://www.bangkokpost.com/business/economics/13762

${ }^{4}$ - http://www.forbes.com/2008/02/29/mitra-india-outsourcing-tech-enter-cx_sm_0229outsource.html
} 
mostly a lagged version of China. Inequality, however, has worsened in China (but with large improvements in absolute poverty) while remaining roughly constant in India.

Table 2.5: Similarities and Differences in China and India's Growth Experiences

Similarities: Growth in Trade and FDI Inflows

\begin{tabular}{l|l|l} 
Trade (Imports+Exports) as \% of GDP & 1990 & 2007 \\
\hline India & 16 & 46 \\
\hline China & 35 & 70 \\
\hline
\end{tabular}

FDI inflows as \% of GDP

\begin{tabular}{l|l|l}
\hline India & $\sim$ & 2 \\
\hline China & 1 & 4
\end{tabular}

Differences: Information technology services and Inequality of Household Income

\begin{tabular}{l|l|l}
$\begin{array}{l}\text { Information Technology Services as \% } \\
\text { of Service Exports }\end{array}$ & 2000 & 2007 \\
\hline India & 32 & 46 \\
\hline China & 6 & 5 \\
\hline
\end{tabular}

\begin{tabular}{l|l|l}
\hline \multicolumn{2}{l}{ Inequality of Household Income } & \multicolumn{2}{l}{ ( } \\
\hline GINI Index India & 0.36 \\
\hline GINI Index China & 0.47
\end{tabular}

Sources: Trade, FDI and Services-World dataBank: http://databank.worldbank.org/ddp/home.do; GINI Index-

http://www.photius.com/rankings/economy/distribution_of_family_income_gini_index_2007_1. $\underline{\mathrm{html}}$ 


\section{The Deepening Trade and FDI Relationship}

India and China are the two most rapidly growing countries in the G20 and also two of the twelve G20 countries with GDP above 1 trillion dollars. While growth accelerated in the 1980's, trade liberalization following 1991 has been an important factor behind India’s postcolonial resurgence level. India's exports have grown steadily since the early 90's barring the two years-1998 and 2009, the years coinciding with the onset of the Asian Financial Crisis and the more recent Financial Crisis.

The trade and other reforms which led to the opening of the Chinese economy in the 90's have also led to a large increase in exports. These have been accompanied by a reduction in the share exports of primary goods from 50\% in 1980 to $5 \%$ in 2008 while the share of manufacturing goods in exports has risen to almost 95\% (China Statistical Year Book, 2009).

Table 3:1 sets out the bilateral trade data. China has become India’s largest trade partner, overtaking the US and UAE in the last two years. After border-trade resumed in July '92, India's exports to China rose sharply, as a fraction of India's total exports they increased from $1.3 \%$ in 1994, to $10.15 \%$ in $2004-05$. They then fell by a couple of percentage points for two years, and then rose again to a high of $11.3 \%$ in 2008 . India is not as significant a trade partner for China as China is for India, but exports to India still account for $2 \%$ of China's total exports world-wide. Bilateral trade between India and China was in excess of $\$ 50$ bn in 2008, only to fall to $\$ 43$ bn during the Financial Crisis in 2009. But what is remarkable is not the only growth of trade but the rate at which it has been growing. Since 2000, India's exports to China grew 7-fold until 2005 and more than 15-fold in the 8 year period 2001-2008. Correspondingly China's exports to India grew 5 times from 2001-2005 and by more than 20 times from 2001-2008. In 2005, at a 
Table 3.1: Comparison of Bilateral Exports as a share of India and China's Total Exports, 1994-2009

\begin{tabular}{|l|l|l|l|l|}
\hline Year & $\begin{array}{l}\text { India's Exports } \\
\text { to China } \\
\text { (\$billion) }\end{array}$ & $\begin{array}{l}\text { Indian Exports } \\
\text { to China (\% of } \\
\text { Total Exports) }\end{array}$ & $\begin{array}{l}\text { China's Exports } \\
\text { to India (\$ } \\
\text { billion) }\end{array}$ & $\begin{array}{l}\text { Chinese Exports } \\
\text { to India(\% of } \\
\text { Total Exports) }\end{array}$ \\
\hline 1994 & 0.32 & 1.28 & 0.57 & 0.473 \\
\hline 1995 & 0.4 & 1.3 & 0.77 & 0.514 \\
\hline 1996 & .72 & 2.17 & 0.69 & 0.455 \\
\hline 1997 & 0.9 & 2.56 & 0.93 & 0.511 \\
\hline 1998 & 0.91 & 2.71 & 1.02 & 0.553 \\
\hline 1999 & 0.83 & 2.31 & 1.16 & 0.596 \\
\hline 2000 & 1.35 & 3.17 & 1.56 & 0.626 \\
\hline 2001 & 1.7 & 3.92 & 1.9 & 0.712 \\
\hline 2002 & 2.28 & 4.62 & 2.67 & 0.82 \\
\hline 2003 & 4.25 & 7.39 & 3.34 & 0.763 \\
\hline 2004 & 7.68 & 10.16 & 5.94 & 1 \\
\hline 2005 & 9.77 & 10.15 & 8.93 & 1.172 \\
\hline 2006 & 10.28 & 8.49 & 14.58 & 1.505 \\
\hline 2007 & 14.62 & 9.94 & 24.01 & 1.972 \\
\hline 2008 & 20.26 & 11.3 & 31.58 & 2.208 \\
\hline 2009 & 13.71 & 8.4 & 29.67 & 2.468 \\
\hline
\end{tabular}

Source: Chinese data- http://www.customs-info.com/; Indian data- http://www.indiastat.com/ 
heads of States meeting both countries set a target of $\$ 30$ bn for bilateral trade by 2010. Bilateral trade in 2004 was $\$ 14$ bn and the target of $\$ 30$ bn was achieved in 2007. The bilateral country trade could now exceed $\$ 60$ bn by the end of 2010 .

India had a small trade deficit with China until 2002. 2003-2005 were better years for the Indian trade imbalance; however, after 2006 the trend reversed significantly with India recording heavy trade deficits.

Table 3.2 reports the growth of India's exports to China and conversely Chinese exports to India. These grew rapidly after reform since the base of trade was low, but an acceleration in this growth has also occurred, barring 2009 after the financial crisis. India's exports to China were affected by the Asian Financial Crisis and the recent Global Financial Crisis, but excluding 2006, bilateral exports have grown by at least 23 \% each year and in three years (1996, 2003 and 2004) touched $80 \%$ growth.

Comparing bilateral export growth data with respective country's overall export growth shows the changes in trade vis-à-vis each other. India has had a significantly larger surge in its exports to China than in its total exports throughout this period except for the two years of the Asian Financial Crisis and 2006. China bilateral trade growth is also more constant when contrasted with India. Only in 1996 did exports to India grow by a smaller amount than total exports. 1996 has been the only year when they recorded negative growth in their exports to India over the last 15 years. Also, the Asian Financial Crisis did not affect China’s exports to India much as export growth stayed near the 15\% mark. Between 2004 and 2007 China’s exports to India grew by more than $50 \%$ a year. 
Table 3.2: Comparison of growth of bilateral exports relative to growth of India and China's total exports, 1995-2009

All figures in \%

\begin{tabular}{|l|l|l|l|l|}
\hline Year & $\begin{array}{l}\text { Growth of India's } \\
\text { Exports to China }\end{array}$ & $\begin{array}{l}\text { Growth of India's } \\
\text { Total Exports }\end{array}$ & $\begin{array}{l}\text { Growth of China's } \\
\text { Exports to India }\end{array}$ & $\begin{array}{l}\text { Growth of China's } \\
\text { Total Exports }\end{array}$ \\
\hline 1995 & 23.55 & 22.42 & 33.55 & 22.95 \\
\hline 1996 & 80.91 & 8.09 & -10.16 & 1.54 \\
\hline 1997 & 24.76 & 5.7 & 35.8 & 21 \\
\hline 1998 & 0.94 & -4.39 & 8.87 & 0.53 \\
\hline 1999 & -8.82 & 6.69 & 14.29 & 6.08 \\
\hline 2000 & 63.9 & 19.62 & 34.32 & 27.84 \\
\hline 2001 & 25.6 & 1.64 & 21.5 & 6.8 \\
\hline 2002 & 33.76 & 13.49 & 40.86 & 22.33 \\
\hline 2003 & 86.97 & 16.72 & 25.16 & 34.59 \\
\hline 2004 & 80.6 & 31.42 & 77.55 & 35.39 \\
\hline 2005 & 27.12 & 27.35 & 50.51 & 28.42 \\
\hline 2006 & 5.23 & 25.75 & 63.21 & 27.16 \\
\hline 2007 & 42.22 & 21.51 & 64.67 & 25.68 \\
\hline 2008 & 38.6 & 21.96 & 31.54 & 17.48 \\
\hline 2009 & -32.33 & -9.03 & -6.06 & -15.98 \\
\hline
\end{tabular}

Source: Chinese data- http://www.customs-info.com/; Indian data- http://www.indiastat.com/ 
Table 3.3 presents month-by-month data on India-China bilateral trade during the recent Financial Crisis. India’s exports to China fell sharply in late 2008 in October and were down by nearly 38\% over the next 10 months. The Indian economy started showing signs of recovery from September 2009. For China the effects are delayed and less pronounced compared to India. China's exports to India fell sharply in November 2008 but dropped by only $7 \%$ over the next ten months. The India's bilateral exports to China have thus been more volatile compared to India's exports, while for China the opposite is true.

In Table 3.4 we present some simple projections of bilateral India-China trade which illustrate its potential future growth. Simple compounding of growth at pre-crisis growth rates suggests a rapidly deepening global joint presence. At current rates of growth by 2015 India will export goods and services worth more than a $\$ 100$ billion to China and its trade (exports) with China will account for more than $20 \%$ of its total exports. China will touch the $\$ 100$ billion mark in 2012 only and by 2015 it would export almost \$ 600 billion of exports to India.

Data on FDI flows is more fragmentary but Table 3:5 indicates that bilateral FDI between China and India remains small although they are growing even more rapidly than trade. From 1997 to 2008 India's investment into China has increased by a factor of 250 although the base in 1999 was less than half a million USD. Similarly, Chinese investment in India has increased by a factor of more than 100 in the past 10 years, again from a small base.

Wei (2005) highlights China’s large domestic market as a major determinant of its inward FDI from OECD countries. For India both the domestic market and cheap labor cost are also important. China's better performance in attracting FDI from OECD countries also reflects 
its trade ties to the OECD. India has advantages of lower labor costs, geographic closeness to OECD, and more cultural similarity and has begun to close the gap more recently.

Table 3.3: Monthly Bilateral Trade data for India and China During the Recent Financial Crisis, January 2007-2010

Growth measured with respect to the same month previous year. All figures are in \%

\begin{tabular}{|c|c|c|c|c|c|}
\hline Year & Month & $\begin{array}{l}\text { Growth of } \\
\text { India's Export } \\
\text { to China }\end{array}$ & $\begin{array}{l}\text { Growth of } \\
\text { India's exports }\end{array}$ & $\begin{array}{l}\text { Growth of China's } \\
\text { Exports to India }\end{array}$ & $\begin{array}{l}\text { Growth of } \\
\text { China's } \\
\text { Exports }\end{array}$ \\
\hline 2007 & Jan-Dec & 42.22 & 21.51 & 64.67 & 25.68 \\
\hline 2008 & Jan-Dec & 38.6 & 21.96 & 31.54 & 17.48 \\
\hline \multirow[t]{5}{*}{2008} & Aug & 31.33 & 27.91 & 30.19 & 21.11 \\
\hline & Sep & 25.56 & 14.78 & 24.07 & 21.41 \\
\hline & Oct & -12.66 & -11.86 & 14.03 & 19.12 \\
\hline & Nov & -51.82 & $\begin{array}{l}-19.26 \\
\end{array}$ & -5.75 & -2.24 \\
\hline & Dec & -49.33 & -1.01 & -1.49 & -2.85 \\
\hline \multirow[t]{12}{*}{2009} & Jan & -59.92 & -12.51 & -17.65 & -17.5 \\
\hline & Feb & -43.95 & -20.98 & -11.92 & -25.72 \\
\hline & Mar & -39.1 & -25.16 & -8.08 & -17.14 \\
\hline & Apr & -51.87 & -22.88 & -13.6 & -22.55 \\
\hline & May & -57.93 & -23.15 & -20.02 & -26.34 \\
\hline & Jun & -49.15 & -20.53 & -25.42 & -21.18 \\
\hline & Jul & -39.34 & -17.9 & -3.85 & -22.87 \\
\hline & Aug & -43.04 & -16.18 & -9.09 & -23.1 \\
\hline & Sep & 11.34 & 1.54 & -8.14 & -15.02 \\
\hline & Oct & -0.88 & 13.91 & -4.15 & -13.69 \\
\hline & Nov & 76.27 & 41.22 & 25.61 & -1.16 \\
\hline & Dec & 71.2 & 26.71 & 38.84 & 17.6 \\
\hline 2010 & Jan & 111.41 & 19.04 & 36.72 & 21.12 \\
\hline
\end{tabular}

Source: Chinese data- http://www.customs-info.com/; Indian data- http://www.indiastat.com/ 
Table 3.4: Forward Projections of India-China Bilateral Trade ${ }^{5}$

\begin{tabular}{|l|l|l|l|l|}
\hline Year & $\begin{array}{l}\text { India's Exports } \\
\text { to China(\$ } \\
\text { billion) }\end{array}$ & $\begin{array}{l}\text { Indian Exports } \\
\text { to China (\% of } \\
\text { Total Exports) }\end{array}$ & $\begin{array}{l}\text { China's Exports } \\
\text { to India(\$ } \\
\text { billion) }\end{array}$ & $\begin{array}{l}\text { Chinese Exports } \\
\text { to India (\% of } \\
\text { Total Exports) }\end{array}$ \\
\hline 2009 & 13.71 & 8.4 & 29.67 & 2.468 \\
\hline 2010 & 19.4682 & 9.85 & 48.9555 & 3.23 \\
\hline 2011 & 27.644844 & 11.56 & 80.776575 & 4.23 \\
\hline 2012 & 39.25567848 & 13.57 & 133.2813488 & 5.54 \\
\hline 2013 & 55.74306344 & 15.93 & 219.9142254 & 7.25 \\
\hline 2014 & 79.15515009 & 18.69 & 362.858472 & 9.50 \\
\hline 2015 & 112.4003131 & 21.94 & 598.7164788 & 12.44 \\
\hline 2016 & 159.6084446 & 25.75 & 987.8821899 & 16.29 \\
\hline 2017 & 226.6439914 & 30.22 & 1630.005613 & 21.34 \\
\hline 2018 & 321.8344678 & 35.46 & 2689.509262 & 27.94 \\
\hline 2019 & 457.0049442 & 41.62 & 4437.690282 & 36.59 \\
\hline 2020 & 648.9470208 & 48.84 & 7322.188966 & 47.92 \\
\hline & & & & \\
\hline
\end{tabular}

\footnotetext{
${ }^{5}$ Forward Projections made assuming the Pre-Crises Growth Rates of 2007
} 
Table 3.5: Bilateral FDI inflows between India and China and total inflows by country, 1997-2009

All figures in \$million

\begin{tabular}{|l|l|l|l|l|}
\hline & \multicolumn{2}{|c|}{ China } & \multicolumn{2}{c|}{ India } \\
\hline Year & Inwards:India & Inwards:Total & Inwards: China & Inwards:Total \\
\hline 1997 & 0.4 & 45257.0 & & \\
\hline 1998 & 5.6 & 45462.8 & & \\
\hline 1999 & 0.5 & 40318.7 & & \\
\hline 2000 & 10.4 & 40714.8 & a & 2315 \\
\hline 2001 & 12.0 & 46877.6 & b & 3402 \\
\hline 2002 & 30.6 & 52742.9 & c & 3234 \\
\hline 2003 & 15.9 & 53504.7 & d & 2057 \\
\hline 2004 & 19.5 & 60630.0 & e & 3258 \\
\hline 2005 & 21.4 & 60324.6 & $\mathrm{f}$ & 4356 \\
\hline 2006 & 52.4 & 63020.5 & g & 14212 \\
\hline 2007 & 34.0 & 74767.9 & 0.7 & 15921 \\
\hline 2008 & 88.1 & 92395.4 & 7.8 & 33027 \\
\hline 2009 & - & - & 44.271 & - \\
\hline
\end{tabular}

$a+b+c+d+e+f+g=2.41$

Source: Chinese data- http://www.customs-info.com/; Indian data- http://www.indiastat.com/ 


\section{The Deepening International Policy Coordination between India and China}

China and India, while building ever deeper trade and FDI links have nonetheless remained distant in geopolitical and security terms. Policies towards Pakistan, nuclear issues, and memories of Chinese adventures in Assam in the 1960's along with the Chinese break with the Soviets at that time remain. But this has not prevented India and China from advancing on several fronts on international economic policy coordination. These developments thus also are part of their growing economic bilateral engagement.

\section{Climate Policy}

In climate policy, China and India signed a five year agreement in October 2009 to jointly fight climate change and to negotiate international climate deals using common positions. Both countries set up a Joint Working Group (JWG) which holds meetings annually in India and China and discusses their respective domestic policies, and also implementation of related cooperative projects. The agreement calls for cooperation on renewable energy and research into the effects of climate change on Himalayan glaciers amongst discussions on domestic initiatives and common political in multilateral negotiations.

This agreement was signed ahead of the United Nations climate-change summit that was held in December 2009 in Copenhagen. It highlights the joint gains from coalitional activities both on climate and other issues. China and India are both members of G20, and have consistently argued that developing countries should not be required to set and meet the same targets for reducing greenhouse gases as developed countries, who have a greater historical responsibility for the increase in atmospheric greenhouse gases. 
Pre-Copenhagen, a joint negotiating position was developed by India, China, Brazil and South Africa (the so called BASIC countries). A proposal made at the Copenhagen Summit requiring developing countries, including India and China, to not exceed their Greenhouse gas emissions after 2025, was unacceptable to both India and China. The BASIC countries prepared their counter-draft well in advance of the Summit, and India and China's cohesion on climate change remained throughout the Copenhagen Summit. They rejected calls by developed nations to set legally binding targets, and India and China then signed a modified Copenhagen Accord in March 2010.

\section{India- China FTA}

India and China have also been discussing a bilateral Free Trade Agreement (FTA) since 2004 as well as a Comprehensive Economic Cooperation Agreement (CECA). A Joint Study Group (JSG) was appointed to discuss possible measures for comprehensive trade and economic cooperation. The study group builds on a mandate contained in the first India-China Joint Declaration signed on June 2003.

The JSG has reported that there had been a high commodity concentration in bilateral trade before 2003. The top ten export products contributed more than $80 \%$ of trade in both directions. It recommended an India-China Regional Trading Agreement, covering trade in goods and services and investment, and identified common ground for trade and investment promotion and facilitation. An important element in the Study was the recommendation that economic cooperation should look beyond simply promoting trade and investment, to

information exchange between government agencies, exchanges of development experience and technology, and industrial cooperation in agriculture and rural development, the electronics 
sector and elsewhere. Since both countries rely heavily on imports of oil and gas and mutual cooperation in energy security was emphasized as of strategic importance.

Following the Joint Study Group, China was reported to be pushing for an FTA in March 2005 with India, which would result in the formation of the biggest free trade area in the World . But in April 2008 India, though wanting closer ties with its neighbor, was firm on a stand of not yet entering a China FTA. A number of reasons were put forward. First, India continued to have substantially higher tariffs than China, so there were potential losses seen from a transfer of tariff revenue to Chinese firms in the form of higher profits. Second, Indian industries opposed the FTA on the grounds a potential surge of cheap imports would result in losses for Indian producers. Third, the Indian Government would have to confer Market Economy status on China, which it did not want to do as it did not deem China's pricing arrangements as transparent.

Dumping has also rapidly grown into a politically sensitive issue that cannot be discounted in FTA negotiations. Between 1995 and 2008, China has had a record 677 antidumping initiations against her, 120 of which were from India. Bilaterally, this is the largest number of cases reported against any exporting country. Next on the list is 84 , which is the number of cases initiated by the entire European Community against China. Conversely, India has been the target of only 4 initiations against them by China ${ }^{6}$.

Beyond the China-India bilateral FTA both an India-ASEAN FTA and a China-ASEAN FTA have been concluded and came into effect in January 2010. In terms of population these are the two largest FTA's in the world, and third and fourth largest in terms of goods and services

\footnotetext{
${ }^{6}$ WTO|Anti-dumping Gateway: http://www.wto.org/english/tratop e/adp e/ad init rep exp e.xls, http://www.wto.org/english/tratop_e/adp_e/ad_init_exp_country_e.xls
} 
traded behind the EU and NAFTA. It can thus be argued that India and China are now involved in an indirect FTA. However according to recent news reports India is already concerned about the rising trade deficit with China due to the China-ASEAN FTA, since China has lowered its tariffs on the goods it imports from ASEAN, creating trade divergence and making it more difficult for India to export to China. The consequent decline in India’s exports to China could thus further increase the trade deficit that India runs with China.

\section{India and China at WTO}

Both India and China also show more evidence of coordinating positions in international negotiating forums and especially the WTO. India was a catalyst in the cessation of Doha Development Agenda (DDA) trade talks at Geneva in July 2008. The broad objective of the DDA was to lower trade barriers across the world so as to allow countries to increase trade globally. For seven years, the talks meandered with frequent disagreements between the developed countries led by the USA and EU, and the developing countries led by the G4 of China, India, Brazil and South Africa. After years of negotiations, all seemed set for a successful conclusion in 2008. But the talks broke down after refusal of the USA to negotiate a 'special safeguard arrangement' in agriculture as India had requested. China supported India's stand. The two countries' mutual support drew widespread criticism from not only developed countries but also from Brazil. But their joint position has preserved since. 


\section{Conclusion}

In the decades ahead if they continue their present growth India and China will each become an even more major presence in the global economy. This has been widely recognized, but what has been less well documented is the even more rapid growth of trade and investment between the two. We emphasize a 33 fold increase in bilateral trade between 1995 and 2007, accompanied by a 100-fold increase in bilateral FDI. Along with this has come with increased international policy coordination between China and India. The world of the early $21^{\text {st }}$ century is thus not only one of rapid growth of low wage large population economies; it is also an even more rapid growth of their bilateral interactions, and hence their emergence as an even more cohesive bloc. 


\section{Bibliography}

(2002, November 20). India and China: Fundamental Differences. Stratfor. Retrieved from http://www.stratfor.com/

(2004, March 25). India, China Hold Talks on Free Trade Agreement. Express India. Retrieved from http://www.expressindia.com

(2005, April 12). India, China to study feasibility of FTA. The Hindu. Retrieved from http://www.hinduonnet.com/

(2008, July 30). India, China not to blame for WTO talks collapse. NDTV Profit. Retrieved from http://beta.profit.ndtv.com/

(2009, December 3). China backs India’s stand on climate change. Indian Express. Retrieved from http://www.indianexpress.com/

(2009, December 9). Denmark’s Draft Deal Earns Ire of Developing Nations. France 24.

Retrieved from http://www.france24.com/en/

(2009, October 21). India, China Sign Climate Pact. The Times of India. Retrieved from http://timesofindia.indiatimes.com/

(2010, April 23). China-Asean FTA May Hit Trade Balance: Scindia. The Economic Times. Retrieved from http://economictimes.indiatimes.com/

Banga,R. (2005). Critical Issues in India's Services-led Growth, Indian Council for Research on International Economic Relations, New Delhi Working Papers 171.

Bhattacharya, S \& Bhattacharyay, B (2006). Free trade Agreement between People’s Republic of China and India: Likely Impact and its Implications to Asian Economic Community. Asian Development Bank, Discussion Paper No. 59. 
Collins, S. \& Bosworth, B. (2008). Accounting for Growth: Comparing China and India. Journal of Economic Perspectives, 22(1), 45-66.

Dasgupta S. (2009, November 28). Copenhagen Conference: India, China Plan Joint Exit. The Times of India. Retrieved from http://timesofindia.indiatimes.com/

Devraj R. (2009, October 27). India-China Deal Reinforces Climate Stand. Inter Press

Service news Agency. Retrieved from http://www.ipsnews.net/

Devraj R. (2009, October 29). India-China Nudge Forward on Climate Issues. Asia Times

Online. Retrieved from http://www.atimes.com/

Einhorn B., Srivastava M. (2008, July 30). WTO: Why India and China said No to U.S..

Business Week. Retrieved from http://www.businessweek.com/

India and China in WTO: Building Complementarities and Competitiveness in the External Trade Sector, Report of a Study, Sponsored by the Planning Commission of India, ISID, April 2006

Joshi S. (2005, March 25). China-India Free Trade Agreement (FTA) Can be the Most Significant Event of the Decade-China Pushes for FTA. India Daily. Retrieved from http://www.indiadaily.com/

Rathore V. (2008, January 20). Service Sector Growth in India and China. The Viewspaper.

Retrieved from http://theviewspaper.net/

Report of the India-China Joint Study Group on Comprehensive Trade and Economic Cooperation

Rodrik, D. and A. Subramanian (2004). From 'Hindu Growth' to Productivity Surge: The Mystery of the Indian Growth Transition, Centre for Economic Policy Research, CEPR Discussion Papers 4371. 
Sen A. (2008, January 15).India, China FTA Prospects Appear Bleak. The Economic Times.

Retrieved from http://economictimes.indiatimes.com/

Sonkar S. (2009, October 21). India-China Signed Five Year Pact to Tackle Climate Change.

Dailynews365. Retrieved from http://www.dailynews365.com/

Srinivasan, T.N. (2004). China and India: Economic Performance, Competition and

Cooperation: An Update, Journal of Asian Economics 15(4),: 613-36.

Stewart H. (2008, July 31). Doha: India accuses US of Sacrificing World’s Poor at Trade Talks. Guardian. Retrieved from http://www.guardian.co.uk/

Tian T.W.G. (2009, March 21). IT Outsourcing: China vs India. Bangkok Post. Retrieved from http://www.bangkokpost.com/

Virmani, A. (2005). Tripolar Century: USA, China and India, Indian Council for Research on International Economic Relations, New Delhi Working Papers 160.

Watts J.( 2009, October 22). China and India agree to cooperate on Climate Change Policy. Guardian. Retrieved from http://www.guardian.co.uk/

Wei, W. (2005). China and India: Any Differences in Their FDI Performances?, Journal of Asian Economics, 16, 719-736

Wheatley J. (2008, August 4). Collapse of Doha Forces Acceptance of Second Best.

Financial Times. Retrieved from http://www.ft.com/home/us

\section{Data Sources}

China Customs Statistics: http://www.customs-info.com/

China Statistics Yearbook 2009, China Statistics Press, October 2009.

Department of Commerce, Government of India:

http://commerce.nic.in/tradestats/indiatrade.asp 
http://www.photius.com/rankings/economy/distribution_of_family_income_gini_index_2007_1.

$\underline{\mathrm{html}}$

India Trade Statistics: http://www.indiastat.com/

World dataBank: http://databank.worldbank.org/ddp/home.do 


\section{CESifo Working Paper Series}

for full list see www.cesifo-group.org/wp

(address: Poschingerstr. 5, 81679 Munich, Germany, office@cesifo.de)

3120 Laszlo Goerke and Markus Pannenberg, 'Take it or Go to Court' - The Impact of Sec. 1a of the German Protection against Dismissal Act on Severance Payments -, July 2010

3121 Robert S. Chirinko and Daniel J. Wilson, Can Lower Tax Rates be Bought? Business Rent-Seeking and Tax Competition among U.S. States, July 2010

3122 Douglas Gollin and Christian Zimmermann, Global Climate Change and the Resurgence of Tropical Disease: An Economic Approach, July 2010

3123 Francesco Daveri and Maria Laura Parisi, Experience, Innovation and Productivity Empirical Evidence from Italy's Slowdown, July 2010

3124 Carlo V. Fiorio and Massimo Florio, A Fair Price for Energy? Ownership versus Market Opening in the EU15, July 2010

3125 Frederick van der Ploeg, Natural Resources: Curse or Blessing?, July 2010

3126 Kaisa Kotakorpi and Panu Poutvaara, Pay for Politicians and Candidate Selection: An Empirical Analysis, July 2010

3127 Jun-ichi Itaya, Makoto Okamura and Chikara Yamaguchi, Partial Tax Coordination in a Repeated Game Setting, July 2010

3128 Volker Meier and Helmut Rainer, On the Optimality of Joint Taxation for NonCooperative Couples, July 2010

3129 Ryan Oprea, Keith Henwood and Daniel Friedman, Separating the Hawks from the Doves: Evidence from Continuous Time Laboratory Games, July 2010

3130 Mari Rege and Ingeborg F. Solli, The Impact of Paternity Leave on Long-term Father Involvement, July 2010

3131 Olaf Posch, Risk Premia in General Equilibrium, July 2010

3132 John Komlos and Marek Brabec, The Trend of BMI Values by Centiles of US Adults, Birth Cohorts 1882-1986, July 2010

3133 Emin Karagözoğlu and Arno Riedl, Information, Uncertainty, and Subjective Entitlements in Bargaining, July 2010

3134 John Boyd, Gianni De Nicolò and Elena Loukoianova, Banking Crises and Crisis Dating: Theory and Evidence, July 2010

3135 Michael R. Baye, Dan Kovenock and Casper G. de Vries, The Herodotus Paradox, July 2010 
3136 Martin Kolmar and Hendrik Rommeswinkel, Group Contests with Complementarities in Efforts, July 2010

3137 Carolina Manzano and Xavier Vives, Public and Private Learning from Prices, Strategic Substitutability and Complementarity, and Equilibrium Multiplicity, July 2010

3138 Axel Löffler, Gunther Schnabl and Franziska Schobert, Inflation Targeting by Debtor Central Banks in Emerging Market Economies, July 2010

$3139 \mathrm{Yu}-\mathrm{Fu}$ Chen and Michael Funke, Global Warming and Extreme Events: Rethinking the Timing and Intensity of Environmental Policy, July 2010

3140 Lawrence M. Kahn, Labor Market Policy: A Comparative View on the Costs and Benefits of Labor Market Flexibility, July 2010

3141 Ben J. Heijdra, Jochen O. Mierau and Laurie S.M. Reijnders, The Tragedy of Annuitization, July 2010

3142 Erkki Koskela, Outsourcing Cost and Tax Progression under Nash Wage Bargaining with Flexible Outsourcing, July 2010

3143 Daniel Osberghaus and Christiane Reif, Total Costs and Budgetary Effects of Adaptation to Climate Change: An Assessment for the European Union, August 2010

3144 Philip E. Graves, Benefit-Cost Analysis of Environmental Projects: A Plethora of Systematic Biases, August 2010

3145 Sabrina Di Addario and Daniela Vuri, Entrepreneurship and Market Size. The Case of Young College Graduates in Italy, August 2010

3146 Shoshana Amyra Grossbard and Alfredo Marvăo Pereira, Will Women Save more than Men? A Theoretical Model of Savings and Marriage, August 2010

3147 Jarko Fidrmuc, Time-Varying Exchange Rate Basket in China from 2005 to 2009, August 2010

3148 Ilja Neustadt and Peter Zweifel, Is the Welfare State Sustainable? Experimental Evidence on Citizens' Preferences for Redistribution, August 2010

3149 Marcus Dittrich and Andreas Knabe, Wage and Employment Effects of Non-Binding Minimum Wages, August 2010

3150 Shutao Cao, Enchuan Shao and Pedro Silos, Fixed-Term and Permanent Employment Contracts: Theory and Evidence, August 2010

3151 Ludger Woessmann, Cross-Country Evidence on Teacher Performance Pay, August 2010

3152 Lorenzo C. G. Pozzi, Casper G. de Vries and Jorn Zenhorst, World Equity Premium Based Risk Aversion Estimates, August 2010 
3153 Volker Grossmann, Thomas M. Steger and Timo Trimborn, Dynamically Optimal R\&D Subsidization, August 2010

3154 Alexander Haupt, Tim Krieger and Thomas Lange, A Note on Brain Gain and Brain Drain: Permanent Migration and Education Policy, August 2010

3155 António Afonso and Christophe Rault, Long-run Determinants of Sovereign Yields, August 2010

3156 Franziska Tausch, Jan Potters and Arno Riedl, Preferences for Redistribution and Pensions. What can we Learn from Experiments?, August 2010

3157 Martin Kolmar and Andreas Wagener, Inefficient Group Organization as Optimal Adaption to Dominant Environments, August 2010

3158 Kai Carstensen, Klaus Wohlrabe and Christina Ziegler, Predictive Ability of Business Cycle Indicators under Test: A Case Study for the Euro Area Industrial Production, August 2010

3159 Horst Rottmann and Timo Wollmershäuser, A Micro Data Approach to the Identification of Credit Crunches, August 2010

3160 Philip E. Graves, Appropriate Fiscal Policy over the Business Cycle: Proper Stimulus Policies Can Work, August 2010

3161 Michael Binder and Marcel Bluhm, On the Conditional Effects of IMF Program Participation on Output Growth, August 2010

3162 Michael Binder, Qianying Chen, and Xuan Zhang, On the Effects of Monetary Policy Shocks on Exchange Rates, August 2010

3163 Felix J. Bierbrauer, On the Optimality of Optimal Income Taxation, August 2010

3164 Nikolaus Wolf, Europe's Great Depression - Coordination Failure after the First World War, September 2010

3165 Dan Kovenock and Brian Roberson, Conflicts with Multiple Battlefields, September 2010

3166 Jean-Pierre Ponssard and Catherine Thomas, Capacity Investment under Demand Uncertainty. An Empirical Study of the US Cement Industry, 1994-2006, September 2010

3167 Jørgen Juel Andersen, Jon H. Fiva and Gisle James Natvik, Voting when the Stakes are High, September 2010

3168 Michael Hoel, Is there a Green Paradox?, September 2010

3169 Scott Alan Carson, Nineteenth Century US African-American and White Female Statures: Insight from US Prison Records, September 2010 
3170 Gil S. Epstein, Yosef Mealem and Shmuel Nitzan, Political Culture and Discrimination in Contests, September 2010

3171 Sara Fisher Ellison, Jeffrey Greenbaum and Wallace P. Mullin, Diversity, Social Goods Provision, and Performance in the Firm, September 2010

3172 Silvia Dominguez-Martinez, Randolph Sloof and Ferdinand von Siemens, Monitoring your Friends, not your Foes: Strategic Ignorance and the Delegation of Real Authority, September 2010

3173 Marcus Dittrich and Beate Schirwitz, Union Membership and Employment Dynamics: A Note, September 2010

3174 Francesco Daveri, Paolo Manasse and Danila Serra, The Twin Effects of Globalization - Evidence from a Sample of Indian Manufacturing Firms, September 2010

3175 Florian Blöchl, Fabian J. Theis, Fernando Vega-Redondo and Eric O’N. Fisher, Which Sectors of a Modern Economy are most Central?, September 2010

3176 Dag Morten Dalen, Marilena Locatelli and Steinar Strøm, Longitudinal Analysis of Generic Substitution, September 2010

3177 Armin Falk, Stephan Meier and Christian Zehnder, Did we Overestimate the Role of Social Preferences? The Case of Self-Selected Student Samples, September 2010

3178 Christian Fahrholz and Cezary Wójcik, The Bail-Out! Positive Political Economics of Greek-type Crises in the EMU, September 2010

3179 Klaus Abberger and Wolfgang Nierhaus, The Ifo Business Cycle Clock: Circular Correlation with the Real GDP, September 2010

3180 Walter Krämer and Gerhard Arminger, "True Believers" or Numerical Terrorism at the Nuclear Power Plant, September 2010

3181 Bernard M.S. Van Praag, Dmitri Romanov and Ada Ferrer-i-Carbonell, Happiness and Financial Satisfaction in Israel. Effects of Religiosity, Ethnicity, and War, September 2010

3182 Dimitrios Koumparoulis and Paul De Grauwe, Public Capital, Employment and Productivity: An Empirical Investigation for Greece, September 2010

3183 John Whalley and Tanmaya Shekhar, The Rapidly Deepening India-China Economic Relationship, September 2010 